\title{
Playing with the Sacred: A Ludic Practice
}

\author{
With Marten van der Meulen
}

\begin{abstract}
A joke [in the passion narrative] is awesome now and then ... after all, this is a spectacle that connects people. But we should not want to include pleasantry that nauseates our Christian supporters. We have to find a balance between the show-character and the seriousness of the narrative.
\end{abstract}

REINDER VAN DIJK (producer for KRO-NCRV), March 22, 2017

(interview by $\mathrm{MK}$ )

While doing participatory observation on the Vismarkt square in the city of Groningen at this fourth edition of The Passion in 2014, my colleague Marten van der Meulen and I both had one eye on our smartphones to see what kind of messages people were posting under the hashtags \#passion and \#tp14 on Twitter. ${ }^{1}$ Amongst the diversity of topics addressed, which included the role of religion, comparisons with previous editions, choice of songs, performance and performers, and expectations that were or were not met, a particular kind of tweet stood out: the humorous ones. People on Twitter played around with jokes, ironic messages, wordplay and other playful messages related to all different aspects of The Passion. Their tweets touched, among other things, on the show, the biblical narrative, the performers, the songs, the square and the

1 This chapter is derived in part from an article published as Mirella Klomp and Marten van der Meulen, "The Passion as ludic practice", Journal of Contemporary Religion 32, no. 3 (2017), 387-401. DOI: 10.1080/13537903.2017.1362879. Author's contributions in this chapter are as follows: I wrote the introduction and the section 'Religious Changes in Late-modern Societies, with the exception of the summary of the work of Ammerman. In the section 'The Passion as Ludic Practice', Van der Meulen wrote the first subsection, the second subsection was written by me. The online ethnographic fieldwork underlying the section 'The Passion as Ludic Practice' was performed by Van der Meulen and myself: we both collected and analysed the data. Together we wrote a draft for the concluding section, which I then revised for the purpose of publication in this book. 
people in the audience. Humour is inherent to social network applications, as scholars in various disciplines have demonstrated. Late professor of sociology and communication Brenda Danet, for example, in 2001 argued that "Cyberspace is often anarchic, playful and even carnivalesque". ${ }^{2}$ Indeed, although digital media are also used for serious discussions and the communication of (real and fake) news, the broad conversational maxim is 'keep it light/fun'. ${ }^{3}$ The Passion seemed, in this sense, to be an object of human play like any other. After we had drawn each other's attention to the abundance of humour, the jokes that were part of the narrative of the play started to stand out. It appeared that, in the changing religious landscape of this late-modern network society, the Christian narrative of the passion has become a subject of playful acting.

'Play' thus struck us as a notion that might enable us to move beyond the religious-secular dichotomy that has dominated theories of religion for decades. ${ }^{4}$ Whilst, during the period in which secularisation theories flourished, lines between religious and secular practices were considered to be rather fixed, the adequacy of this divide has more-recently been contested in various studies of religion and has become a much-debated topic. ${ }^{5}$ Scholars have generally come to acknowledge that these lines are blurring. Modern life is characterised by continuous change, the world has become liquid. ${ }^{6}$ The question of whether we identify ourselves as religious or non-religious may no longer be relevant, now that identity has come down to "stopping being what one is and turning into someone one is not yet". ${ }^{7}$ New media contexts in particular seem capable of evoking, what philosopher Jos de Mul calls, processes of 'ludic self-construction'.

2 Brenda Danet, Cyberpl@y. Communicating Online (Oxford/New York: Berg, 2001), 8.

3 Ana Deumert, "The performance of a ludic self on social network(ing) sites", in The Language of Social Media. Identity and Community on the Internet, eds. Philip Seargeant and Caroline Tagg (Basingstoke/New York: Palgrave Macmillan, 2014), 23-45, here 23.

4 A similar suggestion has been made by André Droogers in his book Religion at play. A Manifesto (Eugene OR: Wipf and Stock, 2014), 45. In this chapter we push the intervention by elaborating concrete examples from the case of The Passion to demonstrate how this works.

5 Cf. for example Jose Casanova, "The Secular, Secularizations, Secularisms", in Rethinking Secularism, eds. Craig Calhoun, Mark Juergensmeyer, and Jonathan Van Antwerpen (Oxford: Oxford University Press, 2011), 54-74; John Seed, “'Secular' and 'Religious'. Historical Perspectives", Social History 39, no. 1 (2014), 3-13; Benjamins, "The Postsecular and Systematic Theology", 116-128.

6 Bauman, Liquid Modernity; Zygmunt Bauman, Liquid Life (Cambridge: Polity Press, 2005).

7 Bauman, Liquid Life, 8.

8 Jos de Mul, "The game of life. Narrative and ludic identity formation in computer games", in Handbook of Computer Game Studies, eds. Joost Raessens and Jeffrey Goldstein (Cambridge, MA: The MIT Press, 2005), 251-266. 
In this chapter we argue that public ritual practices with obvious Christian roots can provide a playing field in which people from a late modern postChristian, post-secular society are able to deal with religion. ${ }^{9}$ We claim that 'play' is an excellent concept to understand and show how this works. Therefore, we ask the question: how does the concept of 'play' help the understanding of public ritual practices such as The Passion event in Dutch society? By studying current public ritual performances from the perspective of play, in combination with media theory and play and game studies, we aim to contribute to the discussion on the way in which religion is changing in late-modern (European) societies.

We begin by discussing André Droogers's theory of play in religion and Nancy Ammerman's notion of sacred consciousness, which both point to people's hermeneutical faculty for dealing with the sacred in their lives. ${ }^{10}$ In liquid modern cultures, this faculty is, time and again, addressed and applied in creative, playful ways. ${ }^{11}$ We relate this to the global ludification of culture a theory developed by Valerie Frissen et al. who argue that 'play', propelled by new technologies, today influences all domains of our culture. ${ }^{12}$ Relating these theories to our case, we present three significant examples from our empirical data, showing how the characteristics of 'play' are worked out in The Passion. Lastly, we draw the conclusion that religion does not escape the influence of a global ludification of culture. ${ }^{13}$ Contemporary Dutch society offers space for religious ludism in rituals like The Passion which trigger people's hermeneutical faculties for dealing with the sacred. In ludic culture, people play with a Christian religious narrative that otherwise seems to be mostly irrelevant.

As mentioned above, passion plays were first performed in the Middle Ages during Lent, particularly in Roman Catholic Western Europe. Today they are still regularly performed throughout the world, mainly in countries where Roman Catholicism has a strong presence, e.g. the Philippines and Brazil (cf. Robin Leaver, "Passion Play", in The Cambridge Dictionary of Christianity, ed. Daniel Patte (Cambridge: Cambridge University Press, 2010), 926). The religious landscape in these cultural contexts is significantly different from the religious landscape that forms the scenery in this monograph.

10 André Droogers, Play and Power in Religion: Collected Essays (Berlin: De Gruyter, 2012); Nancy Tatom Ammerman, Sacred Stories, Spiritual Tribes. Finding Religion in Everyday Life (New York: Oxford University Press, 2014).

11 Bauman, Liquid Modernity; Bauman, Liquid Life.

12 Valerie Frissen et al., eds., Playful Identities. The Ludification of Digital Media Cultures (Amsterdam: Amsterdam University Press, 2015).

13 Another relevant example on the dynamics of religion and ludification is the Church of Fools (later renamed St Pixels). Cf. Tim Hutchings, Creating Church Online. Ritual, Community and New Media (New York: Routledge, 2017), esp. Chapters 4 and 6. 


\section{Religious Changes in Late-Modern Societies}

Late-modern network cultures in the global era are characterised, among other things, by processes of individualisation, fragmentation and interconnectedness, reconstruction of 'self' and 'identity', challenges to tradition and power, continuous reflexivity and flexibility. ${ }^{14}$ The consequences of this cultural backdrop for religion have been discussed by Callum Brown and, for the Netherlands, by Peter van Rooden.

In his study The death of Christian Britain, Brown argues that the decade of the 196os marked a "moral metamorphosis", which transformed the UK from a society with a shared Christian discourse into a society with a "truly secular condition". ${ }^{15}$ Although the religious dynamic in the Netherlands is quite different from that of the UK, the key insight of Brown is similar to what Van Rooden describes. Van Rooden has argued that Dutch Christianity crumbled apart during the massive cultural changes of the 196os, caused by and resulting in a move toward a "reflexive and expressive self". ${ }^{16}$ Previously, people had understood themselves as part of a self-evident ritual order and, when that changed, their religious participation withered away. ${ }^{17}$ Due to depillarisation, the typical top-down ideological authority structures of Dutch society were eroded away and many people lost their religious affiliation or showed more leniency, reflexivity, and choice in their beliefs. ${ }^{18}$ Without question, the changes in the religious landscape since the 196os have been massive. Yet we disagree with Brown that what we experience today is a truly secular society.

At this point, we turn to the recent work of Nancy Ammerman, who introduces the term 'sacred consciousness', as an attribute which many individuals possess, whether or not they are affiliated with religion. ${ }^{19}$ In essence, she

14 Cf. Anthony Giddens, The Consequences of Modernity (Cambridge: Polity, 199o). Bauman, Liquid Modernity; Brian Heaphy, Late Modernity and Societal Change. Reconstruction Social and Personal Life (London: Routledge, 2007).

15 Callum G. Brown, The Death of Christian Britain. Understanding Secularisation, 1800-2000, Christianity and Society in the Modern World (London/New York: Routledge, 2001), $190 ; 1$.

16 Van Rooden, “Oral History", 548. Cf. Chapter 2.

17 Van Rooden argues that one of the differences between the UK and the Netherlands is that the latter did not have a common Christian discourse, but that Dutch society was separated into different pillars which all had their own discursive ritualised ways of living. Van Rooden, "Oral History", 545-546.

18 Willem Frijhoff and Marijke Spies, Dutch Culture in a European Perspective: 1950, Prosperity and Welfare (Assen: Uitgeverij Van Gorcum, 2004), 325.

19 Ammerman, Sacred Stories, 292. 
describes the hermeneutical faculty people possess which enables them to identify the sacred in their lives. Ammerman, alongside others who take a situational approach to the sacred, ${ }^{20}$ places the ability to mark something as sacred or religious in the individual, instead of identifying neatly separated domains as either religious or secular. She argues, for example, that the workplace is not entirely a secular domain. People have the ability to tell stories about work in which they interpret events as having sacred or religious meaning. This makes 'sacred consciousness' essentially hermeneutical. Ammerman argues that "when sociologists study religion, it is this sacred consciousness that is at the heart of our enterprise". ${ }^{21}$ She draws on the work of Durkheim to connect the individual aspects of contemporary religion to communal forms such as congregations, which still have a large influence on people's ability to give mundane events sacred meaning. In our view, the term 'sacred consciousness' also helps to describe how people relate to public events, such as The Passion.

Paying attention to this hermeneutical and individual moment in the construction of religion and/or the sacred is by no means new, but it has become more important in the broader debate on the consequences of late modernity for religion. A liquid modern society is "a society in which the conditions under which its members act change faster than it takes the ways of acting to consolidate into habits and routines", according to Bauman. ${ }^{22}$ In liquid modern life, the sacred is to be found and identified by individuals in new situations and events, again and again. Bauman argues that liquid moderns are accustomed to 'trying on' identities, and that they practise 'spiritual sampling' or the 'taste-testing' of spiritual ideas and practices. ${ }^{23}$ Liquid modern life constantly appeals to people's ability to give meaning to events in their life, including their sacred consciousness. Individuals need to make their own choices, and Ulrich Beck therefore speaks of "institutionalized individualization". ${ }^{24}$ The individual needs to choose a "god of one's own". 25 Considering the fact that the religious field is littered with religious players and sacred forms, such as The Passion, individuals "must negotiate various religious institutions and sacred

\footnotetext{
20 Cf. Chapter 4 where we described sacralising as a human interpretative activity.

21 Ammerman, Sacred Stories, 293.

22 Bauman, Liquid Life, 1.

23 Bauman, Liquid Life, $28 ; 7$.

24 Ulrich Beck, A God of One's Own. Religion's Capacity for Peace and Potential for Violence (Cambridge: Polity, 2010), 95 .

25 Beck, A God of One's Own, 95.
} 
forms in their everyday lives". ${ }^{26}$ This fits with Brown's and Van Rooden's arguments about the transformation of religion which is caused by and results in the rise of the reflexive and expressive self. However, it does not lead to secularity per se, but rather to a flexible, ever changing, and confusingly varied playing field of religious experimentation.

\section{Religion and Play}

The hermeneutical faculty that Ammerman describes has a strong link with the concept of play, particularly in religious and ritual practices. The relation between religion and play has, over time, been discussed at length by various scholars. ${ }^{27}$ For the purpose of this chapter, we focus on the theory of Droogers, a cultural anthropologist of religion who draws extensively on the work of Victor Turner, in particular on liminality and ritual. For Droogers, play is a practice that enables people to create meaning and understand the world around them. His theory illuminates how people play by connecting together

26 See Gerardo Marti and Gladys Ganiel, The Deconstructed Church. Understanding Emerging Christianity (Oxford: Oxford University Press, 2014), 179ff. for an extended discussion of Beck's work in relation to other scholars of religion. The term 'sacred forms' comes from Lynch, The Sacred in the Modern World, 5, 15-17.

27 Anthropologists, sociologists as well as ritual and liturgical scholars have written about play and religion. Cf. the following publications (in chronological order): Romano Guardini, The Spirit of the Liturgy. Trans. Ada Lane (London: Sheed and Ward, 1937 [1935]); Johan Huizinga, Homo Ludens. A Study of the Play-Element in Culture (London/Boston/Henley: Routledge and Kegan Paul, 1949). Originally published as Proeve eener bepaling van het spel-element der cultuur (Haarlem: H.D. Tjeenk Willink \& Zoon., 1938). Ronald L. Grimes, Ritual Criticism. Case Studies in its Practice, Essays on its Theory (Waterloo, Canada: Ritual Studies International, 2010 [199o]); Bernard Lang, Sacred Games. A History of Christian Worship (New Haven: Yale University Press, 1997); Paul Post, "Speelruimte voor Heilig Spel", in Over spel. Theologie als drama en illusie, eds. Herman Beck, Rein Nauta and Paul Post (Leende: Damon, 2000), 139-167; Marcel Barnard and Paul Post, eds., Ritueel Bestek. Antropologische kernwoorden van de liturgie (Zoetermeer: Uitgeverij Boekencentrum, 2001); Brent Plate, "Religion is Playing Games: Playing Video Gods, Playing to Play", Religious Studies and Theology 29, no. 2 (2010), 215-23o; Jaco Hamman, "Playing", In The Wiley-Blackwell Companion, ed. Miller-McLemore, 42-50 (in which he discusses play in/and practical theology; also see the bibliography of that chapter); André Droogers, Play and Power in Religion; André Droogers, Religion at play; Marcel Barnard et al., "Play/Function", in Worship in the Network Culture, eds. Barnard, Cilliers and Wepener, 245-274; Heidi Campbell and Gregory Grieve, eds., Playing with Religion in Digital Games, Digital Game Studies (Bloomington, IN: Indiana University Press, 2014); Stef Aupers, "Spiritual Play: Encountering the sacred in World of Warcraft", in Playful Identities, eds. Frissen et al., 75-92; Simone Heidbrink, Jan Wysocki and Tobias Knoll, eds., "Religion in Digital Games Reloaded. Immersion into the Field", Online - Heidelberg Journal of Religions on the Internet 7 (Heidelberg: University of Heidelberg, 2015). 
two realities simultaneously. He defines play as "the capacity to deal simultaneously and subjunctively with two or more ways of classifying reality". ${ }^{28}$ The term 'subjunctively' is taken from Turner's work and refers to the fact that people can imagine other worlds and other realities 'as if' they are real. ${ }^{29}$ In play, according to Droogers, people can hold two different sets of rules simultaneously and "as long as the game lasts, one set only is valid and creates its own reality. Yet even during the game itself there is the consciousness that when the game is over the other set will prevail". ${ }^{30}$

Droogers gives a decidedly hermeneutical pitch to his theory of play. Putting two realities together simultaneously helps people to explore new ways of seeing things and allows them to participate in a different reality without completely committing to it. After play, people can withdraw from the reality that was explored if it did not meet expectations, or commit more strongly to it if it did. ${ }^{31}$ Crucial to Droogers' theory is the idea that play is not just a cultural phenomenon but also a human capacity, it is an element of humanity's dealing with the world. Play in his view is a human faculty that shapes religious and cultural repertoires and forms.

\section{Ludification of Culture}

'Play as a human capacity' is also the starting point for Frissen et al. in an important cross-disciplinary study on the ludification of digital media cultures. ${ }^{32}$ Whilst the authors clearly consider ludification as a result of play, it could

28 Droogers, Play and Power, 81.

29 Victor Turner, "Frame, Flow and Reflection: Ritual and Drama as Public Liminality", Japanese Journal of Religious Studies 6, no. 4 (1979), 465-499, here 465-466. Also: Victor Turner, The anthropology of performance (New York: PAJ Publications, 1988), 169.

$30 \quad$ Droogers, Play and Power, 81.

31 In line with his theory, Droogers even coined the term methodological ludism as an approach to studying religion: when playing, whether a believer or a non-believer, a researcher can better understand what religion is and means. Or, to use Versteeg's words: "Researchers play along with their informants in a radical attempt to reach verstehen (understanding), without converting to the informant's reality". Peter Versteeg, "Playing Religion? Experience, Meaning and the Ludic Approach", in Anton van Harskamp et al., eds., Playful Religion. Challenges for the Study of Religion (Delft: Eburon, 2006), 97-108, here 98. We have not used Droogers's particular methodology, but see Kim Knibbe et al., "Fieldwork on Ritual. Understanding Through Participation", in Methods for the Study of Religious Change. From Religious Studies to Worldview Studies, eds. André Droogers and Anton van Harskamp (Sheffield: Equinox Publishing, 2014), 87-110, for an application, discussion, and further extension of this theory. 
also be seen as the corollary or epiphenomenon of other large-scale developments such as consumerism or late capitalism. ${ }^{33}$ Nevertheless, Frissen et al. offer an interesting exploration of the relationship between play and identity construction, updating Johan Huizinga's famous theory of Homo Ludens. They emphasize the role of digital media technologies that increasingly shape how people relate to the world, other people, and themselves (as list to which we add their relationship to God/the sacred, as we will elaborate below). Scholars in cultural studies argue that, from the 1960s onwards, playfulness has increasingly become a feature of our culture. We may even speak of a 'ludic turn' or, in the first decade of the 21st century, a global 'ludification of culture. ${ }^{34}$ Today, play permeates every cultural domain, ranging from leisure time, including activities such as shopping, game shows, computer games, internet, tablet and smartphone use, and amusement parks, to more serious fields, such as education (gamification), work (that should mainly be enjoyed), politics (ludic campaigning) and warfare (computer games such as war simulators). ${ }^{35}$ We live in a ludic culture where playfulness is no longer restricted to childhood (as if that was ever strictly the case), but has instead become a lifelong attitude that is clearly visible. Bauman argues that "The mark of postmodern adulthood is the willingness to embrace the game whole-heartedly, as children do". ${ }^{36}$ Hence and this is the same conclusion De Mul arrived at in his research on computer games - our identity has become a ludic subject. ${ }^{37}$ It may be no surprise that ludism occurs in a liquid modern world. When identities are tried on and spiritual sampling is practised, even our religious identity has become a ludic subject.

33 On ludo-industry and ludo-capitalism cf. Julian Dibbell, "The Chinese Game Room. Play, Productivity, and Computing at Their Limits", Artifact 2, no. 2 (2008), 82-87. Cf. also Pedro Rey, "Gamification and Post-Fordist Capitalism", in The Gameful World. Approaches, Issues, Applications, eds. Steffen P. Walz and Sebastian Deterding (Cambridge (MA): The MIT Press, 2014), 277-295.

34 On 'ludic turn', cf. Judith Thissen, Robert Zwijnenberg, and Kitty Zijlmans, Contemporary Culture. New Directions in Art and Humanities Research (Amsterdam: Amsterdam University Press, 2013), 12. Cf. also Joost Raessens, "The Ludification of Culture", in Rethinking Gamification, eds. Mathias Fuchs et al. (Lüneburg: Hybrid Publishing Lab, 2014), 91-114, here 109-111, http://gamification-research.org/2014/o6/edited-volume-rethinking -gamification-out/. Last accessed October 31, 2019. On 'ludification of culture', cf. Frissen et al., Playful Identities, 9.

35 Frissen et al., Playful Identities, 9.

36 Zygmunt Bauman, Life in Fragments. Essays in Postmodern Morality (Oxford: Blackwell Publishers Ltd., 1995), 99.

De Mul, "The game of life", 26o-261. 
Technology and digital media play an important role in this ludic turn. Frissen et al. propose four characteristics of digital media: (1) multimediality: a multitude of means of expression that lead to a multisensory experience as well as a shared digital code (software permeates almost every aspect of our lives), (2) virtuality: immersive experiences, evoked by simulation technologies, and metaphorical spaces created by communication networks, where the real and the virtual are connected, (3) interactivity/participation: users can intervene in a meaningful way within the representation itself, either through designed choices and procedures or by participating beyond the object, (4) connectivity: Facebook is the best-known example of this; it is a site where people connect around individuals, but also around topics or events, in communities. ${ }^{38}$ Furthermore, Frissen et al. propose that digital media, seen as playful practices, are characterised by four ambiguities: (a) reality and appearance are interrelated, (b) freedom and force: we can play and we are beingplayed at the same time, (c) determination and change: the final phase always becomes outdated by the arrival and claims of newer media, (d) individuality and collectivity: the identity of individual media in a media landscape where different media systems are converging. ${ }^{39}$

In summary, we may say that, in a globally ludifying culture, in which institutionalised Christianity has crumbled and authority structures have collapsed, the reflexive and expressive self has risen and people have more space for leniency, reflexivity, and choice in their beliefs. In such a culture, people's sacred consciousness as well as their capacity to deal simultaneously and subjunctively with two or more ways of classifying reality is constantly being spoken to. In this cultural context, a public ritual based on the Christian passion narrative in the Netherlands can become highly popular. What insights does the notion of play offer to our understanding of public ritual practices similar to The Passion event in Dutch society?

\section{The Passion as Ludic Practice}

As we have already discussed, the organizers of the show use popular Dutch hit songs and put the lyrics into the mouths of the main characters. When sung as a duet by Jesus and Judas, a love song normally sung by a couple is imbued with a new and/or different meaning, adding an extra layer. The format consists of a

38 Frissen et al., Playful Identities, 22.

39 Frissen et al., Playful Identities, 28-29. 
constant interplay between two or more realities, and the audience are invited to do the same. In the following sections, using both the lens of Droogers's theory and the ludification theories offered by Frissen et al., we will analyse how play works in and around the performance. We first present some general observations about this ludic practice and then further elaborate by discussing three striking examples. In each example, both the organizers and the public are players. We describe the realities that are simultaneously being connected, the (digital) media which are involved, the characteristics and ambiguities that play a role, and the broader issues that are at stake.

\section{General Observations}

Throughout The Passion event, broadcasting companies and the producer, as well as the public, all engage in various media at the same time. Of course, the stage action that is broadcast live is the most crucial part. In addition, before, during, and after the event the organizers intensively use their Facebook account in order to build a community of 'likers', thus stimulating connectivity and their Twitter account @thepassion in order to stimulate interactivity, frequently employing visuals and videos that combine polished images, sounds, and texts (multimediality). The public engages in social media independently or in response to the organizers' social media activities. The organizers generate media attention for those who are to be that year's performers with interviews on www.thepassion.nl and on $\mathrm{TV}$ and radio talk shows (multimediality) and invite people to respond through social media, for instance, by employing share-and-win-techniques (interactivity). The procession that becomes part of The Passion bears all four characteristics of playful digital media practices. It combines the physical walk through the streets, the broadcast of the procession, and the virtual procession via the Internet (multimediality). It connects the real and the virtual by giving the offline procession an online counterpart, based on a software application (virtuality). It enables people to type their motivations into the textbox, thus generating participation (explicit interactivity). The way in which these motivations pop-up on people's devices during the virtual procession, on the screen on the stage, and in the live-broadcast connects people and their play (connectivity).

In short, as a multimedia event, The Passion appears to have all the characteristics of a ludic practice as identified by Frissen et al. ${ }^{40}$ In other words, the digital media in this case clearly offer users new opportunities to play with a Christian narrative. We will now go deeper by examining three specific examples. 


\section{The Dutch Queen of Plastic Surgery in the Role of the Servant Girl}

Humour, and more specifically irony, is a form of play that is regularly applied in and around The Passion..$^{41}$ Our analysis of tweets shows that many people make jokes about The Passion, for example, "They should make a book about this \#tp1 $5^{\text {"42 }}$ - a simple joke, as, of course, that book already exists in the world outside the play. Before The Passion had even begun, several people had already tweeted that they were looking forward to humorous comments. Many people actively wait for the 'fun' element of The Passion, as alluded to in the tweet "I am ready for it! Next 2.5 hours I am not approachable. Lots of fun! \#Passion \#Passion2015 \#passion15 \#thePassion". ${ }^{43}$ Strikingly, many Dutch comedians lie in wait to play with The Passion. Yet, it is not just the public that makes jokes around The Passion: the organizers also employ humour in The Passion. In the 2015 edition, the scene in which Peter denies Jesus starts with "the Dutch icon of plastic surgery", ${ }^{44}$ Marijke Helwegen, in the role of a servant girl, saying that she recognizes Peter as one of the friends of Jesus. ${ }^{45}$ She walks a Chihuahua dog to whom she says: "Come, Goliath, come and pee..." The actress was reverse typecast for the role of servant girl, as the organizers chose a woman in her sixties who constantly tries to retain her youthfulness and so was the tiny dog, who was named after Goliath, the biblical giant. Here, the reality of the biblical characters of servant girl and Goliath were combined with the realities of, respectively, the contemporary beauty industry and the practice of keeping tiny dogs as pets. This scene immediately evoked various comments on Twitter. Some tweets showed that people appreciated this playful combination of realities, while other tweets were negative, and some people were obviously provoked into play themselves by making jokes on Twitter. ${ }^{46}$ These are all clear examples of beyond-the-object-interactivity (people participating within the culture of the object), they did not directly influence the

41 Humor, which is related to play in the sense that it also combines different realities, is a research topic of its own that goes beyond the scope of this chapter. We confine ourselves to mentioning humour as one possible form of play.

42 Passion-Archiver excel sheet \#4871. All quotations from the digital media in this chapter are originally in the Dutch language and were translated into the English by the authors.

43 Passion-Archiver excel sheet \#4666.

44 "Marijke Helwegen", Wikipedia The Free Encyclopedia, July 12, 2016. https://nl.wikipedia .org/wiki/Marijke_Helwegen. Last accessed May 10, 2020.

45 "The Passion 2015", NPO Start, EO/KRO, video, 1:34:०0, at 55:o8, https://www.npostart.nl/ the-passion-2015/O2-04-2015/VPWON_1240591. Last accessed October 31, 2019.

46 E.g. appreciation: Passion-Archiver excel sheet \#1897; discontent: "too much" \#19o9, "bad combination" by @[pastorı], tweet, April 2, 2015 at 1.19 p.m.; "too much of a parody" by $@$ [pastor2], tweet, April 2, 2015 at 1.21 p.m., jokes: Passion-Archiver excel -sheet \#2918, \#2891, \#3419. 
performance on the stage or the live broadcast, but contributed to the interactive discussion via digital media. ${ }^{47}$ Here the public played and was at the same time played by the organizers; thus we recognize the ambiguity of freedom versus force, as discussed by Frissen et al. ${ }^{48}$

The use of the Dutch queen of plastic surgery as the servant girl is just one example of a scene in which the producers deliberately connected contemporary and biblical realities so as to result in a humorous effect. In the deliberate application of humour in the representation of the Christian passion narrative, the 'as if'-character of play that combines different realities enables players to either withdraw from the reality that is explored or to commit more strongly to it. For some people, this created a distance between themselves and the narrative: a relativisation that is potentially useful when a religious story is staged that runs the risk of being ridiculed or rejected ${ }^{49}$ Since the production and broadcasting companies aim for high viewing figures, this distance is employed to make the event accessible to a broad and diverse public. Yet, in a secularising country where practices of spiritual sampling are important, it also enables people to commit to the reality that even Marijke Helwegen can play a part in the narrative on Christ. ${ }^{50}$ Apparently, the God-story can even be about you or me or anyone. The ludic passion practice can lead people to try on a religious identity and see how it fits. Religious identity thus no longer has to be seen as a fixed given but, rather, can take on something of a ludic character.

Whilst this scene did result in some people withdrawing from the reality being explored, the point here is that humour opens possibilities for players to

47 Interestingly, Wikipedia has a more elaborate definition of 'second screen' than the Oxford Dictionary (cf. Chapter 3, footnote 13), which emphasises its potential to generate an online conversation around the content: "A second screen involves the use of a computing device (commonly a mobile device, such as a smartphone or tablet) to provide an enhanced viewing experience for content on another device, such as a television. (...) The use of a second screen supports social television and generates an online conversation around the specific content". "Second Screen", Wikipedia The Free Encyclopaedia. https://en.wikipedia.org/wiki/Second_screen. Last accessed May 10, 2020.

48 Frissen et al., Playful Identities, 28.

49 The distance or relativisation (including the assessment of its appropriateness) is not unequivocal, as became clear in a Twitter discussion between two Protestant pastors. Regarding the participation of Marijke Helwegen and a couple of other celebrities, @[pastor1] spoke of "stylistic ruptures that undermined the narrative", tweet of April 2, 2015, whereas @[pastor2] said in response to @[pastor1] that, in her opinion, there was too much parody included in this version, tweet of April 2, 2015.

50 Passion-Archiver excel-sheet, tweet \#1963: "Marijke Helwegen in the Passion \#amazing \#tp15". 
play, that is, to see or experience things they had not seen or experienced before. It addresses the human hermeneutical faculty for dealing with the sacred in one's life, and, vice versa, to see one's life in light of the sacred.

\section{After His Arrest Jesus Christ Appears in an Iconic Orange Jumpsuit}

Some elements of the show derive new meaning from images and topics that have previously been seen and discussed in the media. A particularly prominent example of this is the orange jumpsuits of Barabbas and Jesus. Since the first edition in 2011, Jesus and Barabbas have, every year, worn orange coveralls when they appear before Pontius Pilate as detainees (see figure 11 in the next chapter). The desirability of choosing orange has been much debated by the public from the start but, in 2015 in particular, it became a hot topic. It reminded the public, as demonstrated by several tweets, of the Isis practice of killing prisoners in orange coveralls. A few weeks earlier, photos of ISIs terrorists in black clothing killing Coptic Christians in very similar orange coveralls on a Libyan beach had reached the front pages of the Dutch news media. On the morning of the performance, 2 April 2015, the news media broke the story of the killing of the 147 Kenyan students by ISIs. Many people referred to this event in tweets about The Passion. Interestingly, in previous years, people had associated the coveralls with the prisoners in Guantanamo Bay, an association that was probably intended by the organizers who, from the very first edition, had been keen on connecting The Passion to contemporary debates. ${ }^{51}$

Comments about The Passion in digital media prominently featured discussion about Islam. On the second screen, a Muslim texted his personal motivation for walking in the virtual procession:

I walk along as a Muslim in this world much is rotten which I cannot help but I can walk along with the cross and thereby contribute to a peaceful world 'cause in the end we are all human. ${ }^{52}$

The following tweet combines - with an intentionally humorous or perhaps even ironic tone - discussion of Islamisation with what is happening on the screen and 'on the couch' where people watch the show:

$5^{1}$ The prevalence of these kinds of comments shows that a religious play can engender public reflection and discussion about contemporary topics, a point that Turner already stressed. "Public reflexivity takes the form of a performance", he argued. Cf. Turner, "Frame, Flow and Reflection", 465. Also see Victor Turner, From Ritual to Theatre. The Human Seriousness of Play (New York: Performing Arts Journal Publications, 1982), 13.

$5^{2}$ Motivations virtual procession-excel sheet (2015) \#6084. Document obtained via broadcasting company EO. 
The fact that more than 4 million people watch a public crucifixion eating popcorn and crisps offers possibilities for islamisation \#tp15. ${ }^{53}$

This is another example of how, in digital media, different realities are playfully combined at once: the reality of the show itself, the reality of the people sitting in front of a TV screen, the reality of the current discussion about Islamisation in the Netherlands, and the reality of the violence which is associated with Islam and of which people had seen many examples on $\mathrm{TV}$ in the weeks preceding the show. The storm in a teacup brought about by the orange jumpsuits on social media strikingly reflects the ambiguities of freedom and force, and of reality and appearance that surround digital media. Part of the public resented the choice of the costumes in this play. They had the freedom to play along, yet they could not escape the organizers' design. In this case, the design troubles them and they have no influence. The interactivity of digital media (one of its characteristics), however, enables them critically to comment on the design choice of the costumes via social media.

\section{An Accused Actor in the Role of Barabbas}

*spoiler alert* The inhabitants of Enschede will again crucify Jesus. Despite the fact that @daveroelvinkı plays Barabas [sic] \#thepassion. ${ }^{54}$

One topic that provoked a torrent of tweets was the participation of Dave Roelvink in The Passion as Barabbas. Dave is the son of Dries Roelvink, a celebrity folk singer (although many consider him as a B-list celebrity). Dries' son was relatively unknown until he achieved national notoriety in August 2014 when a sex video appeared on YouTube of an orgy in which Dave had participated. A woman figuring in the video brought a lawsuit against Dave and also accused him of theft. In the tweet quoted above, different realities are referred to. First the "*spoiler alert" is a typical joke because many people already know that Jesus is the one who will be crucified. "The inhabitants of Enschede" is a reference to the place where The Passion was held, which brings together, itself, a combination of realities, because originally, of course, it was the people in first-century Jerusalem who crucified Jesus. The tweet expresses amazement that Barabbas again is 'off the hook', "despite the fact that @daveroelvinkı plays Barabas", which suggests that the tweeter thinks

53 Passion-Archiver excel-sheet, tweet \# 3285 .

54 Passion-Archiver excel-sheet, tweet \#6228. 
that Dave Roelvink is a much better candidate for crucifixion than the real Barabbas ever was.

People were surprised that Dave Roelvink appeared on the show as Barabbas. Several members of the media picked up this sentiment. De Telegraaf, the largest national newspaper in the Netherlands, held an online poll asking people whether they thought it was alright that someone of disrepute (although Dave Roelvink had not been convicted yet) participated in The Passion. Remarkably, $72 \%$ of the people who responded to the poll were against the participation of Dave Roelvink. ${ }^{55}$ The Passion organizers responded with an official statement:

Exactly by giving this role to Dave and the resistance that this evokes, The Passion shows the injustice/unfairness of the fact that Jesus was condemned instead of Barrabas [sic]. ${ }^{56}$

The following day, the popular TV show "RTL Late Night" picked up the topics of the orange coveralls and the participation of Dave Roelvink and questioned the director about the reasons why the organizers had selected Roelvink. the director paraphrased the official statement. This is another example of the 'convergence' that is part of the ambiguity of individual media versus collective media: there is "an ongoing process or series of intersections between different media systems", in this case, TV, the internet site of a newspaper, and Facebook. ${ }^{57}$

This example can be seen as a public thematisation of a moral topic, i.e. whether someone of disrepute should have positive public recognition on a TV show, even when playing a criminal. There are hints of religious elements too. Part of the public disapproval seems to be related to the fact that Dave Roelvink participated in a religious event, which apparently still has a sacred quality. Interestingly, the discussion did not take place within a single site, but across different, converging media. This demonstrates the continuing possibility for religion to engender and channel public debate.

55 See De Telegraaf. "Eo de mist in met Dave Roelvink", April 1, 2015. https://www.telegraaf .nl/entertainment/837013/eo-de-mist-in-met-dave-roelvink. Last accessed May 10, 2020.

56 Quotation from the statement made on the Facebook page of The Passion organisation, April 1, 2015 at 1.21 a.m. The statement was repeated in a number of social media and in official TV interviews.

57 Frissen et al., Playful Identities, 29. They quote Henry Jenkins, Convergence culture. Where old and new media collide (New York: New York University Press, 2006), 282. 


\section{Conclusion}

Returning to the central question of this chapter, we argue that in late modern society people engage in public ritual practices which have Christian roots in a playful manner, thereby sampling and tasting what is offered. This sampling and tasting are enabled by various digital media that both the organizers and the public employ. In doing so, the public relates to Christian and religious narratives that for a large portion of these people otherwise seem to be mostly irrelevant. This ludic practice, through various digital and non-digital media, offers participants the possibility to engage in an event about the story of the suffering and death of Jesus without necessarily committing themselves wholesale to a religious cosmology or morality. The 'as-if' character, which, for many people in a secularising society, comes with play, legitimizes their participation in an event based on a religious narrative. In employing digital media, they also engage in the religious narrative by playfully connecting it to broader societal and moral issues: societal concerns regarding 'Islamisation' (particularly related to violence by Isis that has recently been on the news), and the moral issue of people accused of wrongdoings being (un)worthy to play a role in the event. This result is in line with the observation by Stef Aupers who, in an article on spiritual play, argues that online game play provides "an unacknowledged epistemological avenue to interact with the sacred and to contact the ultimate values that, Max Weber (1919) argued, retreated from modern life". ${ }^{5}$ Understanding The Passion as play thus explains how people's hermeneutical faculty for dealing with the sacred in the world can be addressed. A recommendation for future research is to further investigate the relation between this public ritual and meaning-making on the part of individuals: what meaning do they ascribe to this ludic practice? Can this be seen as 'sacred' and, if so, in what way?

People's dealings with Christian ritual repertoire, symbols and narratives do not escape the influence of the global ludification of culture, as we have shown, and are strongly influenced by digital media. They acquire multimedial, virtual, interactive and connective traits and are affected by the ambiguities of playful practices. Therefore, we should be wary of seeing Dutch society as truly secular or of seeing an event like The Passion as a return to religion. Ludic practices such as The Passion may be recognised as events where the antithesis between the religious and the secular grows weak or even disappears.

$5^{8}$ Aupers, "Spiritual Play", 76. Aupers here refers to Max Weber, "Science as a vocation". in From Max Weber: Essays in sociology [1919], eds. Hans H. Gerth and C. Wright Mills (London: Routledge, 1948), 129-156. 
Offering a playground or an interface, these events trigger (or even induce) people's hermeneutical faculties for the sacred in a way which is very similar to Ammerman's 'sacred consciousness' and Bauman's 'trying on identities'. Today, religious identity is often not a fixed but a playful phenomenon. The concept of play helps to resolve the paradox that, in a (still) secularising country such as the Netherlands, a performance of the core Christian narrative can be so popular. 'Play' makes the religious-secular dichotomy irrelevant: institutionalised religion in late modern Dutch society is undeniably in decline but, at the same time, religion, and engagement with the sacred, are ludic practices that are very much alive. 